\title{
CURAHAN WAKTU KERJA WANITA TANI SEBAGAI BURUH PETIK MELATI GAMBIR DAN KONTRIBUSINYA TERHADAP PENDAPATAN RUMAH TANGGA
}

\section{TIME SPEND OF WOMAN FARMERS AS MELATI GAMBIR PICKERS AND THEIR CONTRIBUTION TO HOUSEHOLD INCOME}

\author{
Muhammad Fauzan*, Ulil Martinah, Lestari Rahayu \\ Program Studi Agribisnis Fakultas Pertanian Universitas Muhammadiyah Yogyakarta \\ *E-mail: muhammad.fauzan@umy.ac.id \\ (Diterima 21-06-2020; Diterima 22-07-2020)
}

\begin{abstract}
ABSTRAK
Penelitian ini bertujuan untuk menganalisis curahan waktu kerja buruh petik melati gambir dan kontribusinya terhadap pendapatan rumah tangga di Kecamatan Bukateja Kabupaten Purbalingga. Penelitian ini mengggunakan data primer hasil survei pada 52 responden dengan menggunakan kuesioner dan dianalisis secara deskriptif. Hasil penelitian menunjukkan bahwa curahan waktu kerja wanita tani sebagai buruh petik melati gambir adalah sebesar $37 \mathrm{jam} / \mathrm{minggu}$. Pendapatan buruh petik melati gambir sebesar Rp 596.346,-/bulan dan memberikan kontribusi sebesar 25,58\% terhadap pendapatan total rumah tangga.
\end{abstract}

Kata kunci: buruh petik, curahan waktu kerja, pendapatan rumah tangga, wanita tani

\section{ABSTRACT}

This study aims to analyze the time spent of melati gambir pickers and their contribution to household income in Bukateja District, Purbalingga Regency. This study uses primary data from 52 respondents using a questionnaire and analyzed descriptively. The results showed that the time spend by melati gambir pickers was 37 hours / week. The income of melati gambir pickers was Rp. 596,346 / month and contributes $25.58 \%$ to total household income.

Keywords: picker labors, time spent working, household income, woman farmers

\section{PENDAHULUAN}

Kondisi ekonomi petani dan keberlangsungan usahatani sedikit banyak tergantung dari tersedianya lahan yang memadai untuk kegiatan pertanian. Namun, laju konversi lahan pertanian ke nonpertanian yang semakin masif, mengakibatkan berkurangnya lahan pertanian dan luasan lahan yang diusahakan petani pun menjadi semakin sempit. Dalam kondisi demikian, lahan tidak mampu menyediakan pekerjaan bagi seluruh anggota rumah tangga petani sehingga pendapatan petani semakin rendah.

Peran dan posisi kaum wanita pun terus berkembang hingga ditempatkan sebagai mitra yang sejajar dengan kaum pria. Fenomena wanita bekerja pada sektor pertanian bagi masyarakat pedesaan bukanlah hal yang baru. Karena mayoritas mata pencaharian penduduk desa adalah bertani, maka kebanyakan wanita yang ikut bekerja dalam 


\section{CURAHAN WAKTU KERJA WANITA TANI SEBAGAI BURUH PETIK MELATI GAMBIR DAN \\ KONTRIBUSINYA TERHADAP PENDAPATAN RUMAH TANGGA \\ Muhammad Fauzan, Ulil Martinah, Lestari Rahayu}

membantu perekonomian keluarga pun bekerja pula di bidang pertanian, utamanya sebagai buruh tani.

Kegiatan usahatani yang dilakukan wanita tani dipengaruhi oleh curahan waktu kerja. Curahan waktu kerja wanita tani dalam kegiatan yang ekonomi banyak dipengaruhi oleh faktor sosial ekonomi dan keadaan keluarganya. Faktor-faktor sosial ekonomi yang berpengaruh pada curahan waktu kerja wanita tani adalah tingkat umur, jumlah tanggungan keluarga, tingkat upah, luas lahan, status perkawinan, tingkat pendidikan, dan tingkat pengalaman.

Di Kecamatan Bukateja Kabupaten Purbalingga, mayoritas kaum wanita bekerja sebagai buruh petik melati gambir di lahan kebun milik petani mitra perusahaan teh. Dalam satu ha lahan dibutuhkan 4 orang buruh untuk memetik kuncup bunga melati gambir setiap harinya. Hal ini membuka lapangan pekerjaan bagi kaum wanita yang membutuhkan tambahan pendapatan untuk mencukupi kebutuhan rumah tangga.

Keterlibatan kaum wanita untuk bekerja di sektor pertanian ini menjadikannya memiliki peran ganda, yaitu peran sebagai ibu rumah tangga dan peran di sektor publik untuk mencari nafkah guna membantu pendapatan keluarga. Untuk itu, penelitian ini bertujuan untuk menganalisis curahan waktu kerja buruh petik melati gambir dan kontribusinya terhadap pendapatan rumah tangga.

\section{METODE PENELITIAN}

Penelitian dilakukan di Desa Karangcengis Kecamatan Bukateja Kabupaten Purbalingga. Lokasi tersebut dipilih karena merupakan desa dengan jumlah buruh petik melati gambir terbanyak di Kecamatan Bukateja. Penentuan responden dilakukan dengan metode simple random sampling kepada 52 orang wanita tani. Data dikumpulkan dengan teknik wawancara menggunakan kuesioner terstruktur.

Untuk mengetahui curahan waktu kerja buruh petik melati gambir dilakukan penghitungan jumlah jam yang wanita tani curahkan dalam pekerjaannya selama 1 pekan. Data kemudian dibandingkan dengan kriteria Faqih (2011) yang menyatakan bahwa curahan waktu kerja buruh termasuk kategori tinggi jika lebih dari atau sama dengan 35 jam/pekan, dan termasuk rendah jika kurang dari 35 jam/pekan. Pendapatan rumah tangga wanita tani dihitung dengan menjumlahkan total pendapatan 
dari kegiatan on farm, off farm, dan non farm selama 1 bulan. Kontribusi pendapatan sebagai buruh petik melati gambir terhadap total pendapatan rumah tangga dihitung dengan bentuk persentase.

\section{HASIL DAN PEMBAHASAN}

Curahan Waktu Kerja Wanita Tani sebagai Buruh Petik Melati Gambir

Rata-rata curahan waktu kerja wanita tani sebagai buruh petik melati gambir adalah 37 jam/minggu. Kegiatankegiatan yang dilakukan meliputi persiapan sebelum pemetikan, berupa penyiapan wadah berupa ember untuk menampung hasil petikan, dan topi serta kain untuk melindungi diri dari panasnya sinar matahari. Setelah kegiatan pemetikan selesai, buruh petik menyetorkan hasil petikannya ke rumah tengkulak. Pada kegiatan penyetoran ini, buruh petik umumnya berjalan kaki dari lokasi kebun ke rumah tengkulak. Beberapa orang buruh petik menggunakan sepeda menuju rumah tengkulak, namun jumlahnya sangat sedikit. Agar tidak terjadi antrian yang panjang saat penyetoran, tengkulak telah membagi waktu setor untuk masingmasing kelompok buruh petik. Masingmasing buruh petik umumnya menghabiskan waktu sekitar 10-15 menit untuk menyetorkan hasil petikannya.

Rata-rata curahan waktu kerja buruh petik melati gambir selama 37 jam/minggu termasuk tinggi, jika mengacu pada Faqih (2011). Jika diasumsikan buruh petik bekerja selama 6 hari dalam seminggu, maka rata-rata curahan waktu kerjanya adalah 6,2 jam/hari.

Kegiatan utama buruh petik berupa pemetikan melati gambir umumnya dilakukan pada pagi hari, antara jam 06.00 sampai dengan jam 10.30. Pemetikan dilakukan pada kuncup melati gambir yang belum mekar, sesuai dengan permintaan tengkulak. Jika hasil petikan berupa kuncup bunga yang sudah mekar maka akan ditolak oleh tengkulak dan juga pabrik.

Dalam sehari, wanita tani mampu mendapatkan hasil petikan melati gambir sebanyak 1,5 - $2 \mathrm{~kg}$. Harga yang diterima sebesar Rp 18.000/kg. Upah yang diterima buruh petik setelah dilakukan penimbangan adalah Rp 10.000/kg. Sisanya sebesar $\mathrm{Rp} 8.000 / \mathrm{kg}$ diberikan untuk pemilik lahan. Sistem pembayaran oleh tengkulak kepada buruh petik dilakukan dengan sistem tengah bulanan, yaitu sistem pembayaran dua kali dalam sebulan. Hal tersebut dilakukan sesuai 


\section{CURAHAN WAKTU KERJA WANITA TANI SEBAGAI BURUH PETIK MELATI GAMBIR DAN \\ KONTRIBUSINYA TERHADAP PENDAPATAN RUMAH TANGGA \\ Muhammad Fauzan, Ulil Martinah, Lestari Rahayu}

dengan kesepakatan antara pemilik lahan dengan tengkulak dan buruh petik itu sendiri. Setiap 15 hari sekali, pemilik lahan bersama dengan buruh petik, akan menerima uangnya di rumah tengkulak tersebut.

Setelah kegiatan penyetoran hasil petikan kepada tengkulak selesai, umumnya buruh petik melakukan pekerjaan lain seperti menjadi buruh tani, pengrajin rambut palsu (wig) dan berdagang. Namun, ada juga buruh petik yang tidak memiliki pekerjaan lain sehingga setelah pulang ke rumah hanya melakukan kegiatan rumah tangga atau beristirahat.

Curahan waktu kerja buruh petik melati gambir sebesar $37 \mathrm{jam} / \mathrm{minggu}$ ini lebih rendah dibandingkan dengan buruh petik bawang merah di Kabupaten Brebes (Lailandra et al, 2019) dan karyawan petik teh di Sumatera Utama (Purba et al, 2017), namun lebih tinggi dari buruh petik teh di Kabupaten Pemalang (Wibawa, 2019). Menurut Mausyaroh et al (2010), semakin tinggi curahan waktu kerja buruh petik maka semakin tinggi pula pendapatan yang akan didapatkan. Pendapatan ini yang kemudian akan digunakan untuk memenuhi kebutuhan sehari-hari (Fauzan, 2016).

\section{Curahan Waktu Kerja Wanita Tani dalam Kegiatan Ekonomi}

Selain bekerja sebagai buruh petik melati gambir, wanita tani juga memiliki kegiatan ekonomi lainnya, untuk memenuhi kebutuhan rumah tangganya. Secara umum, jenis kegiatan ekonomi tersebut dapat dikelompokkan dalam tiga kategori (Risnawati \& Tridakusumah, 2020), yaitu kegiatan ekonomi on farm, off farm, dan non farm (non pertanian). Menurut Suratiyah (1994), pendapatan on farm adalah pendapatan yang berasal dari hasil usahatani milik sendiri, pendapatan off farm adalah pendapatan yang bersumber dari hasil berburuh tani diluar usahatani milik sendiri atau bekerja di usahatani milik orang lain, dan pendapatan non farm adalah pendapatan yang bersumber selain dari usaha pertanian.

Tabel 1. Curahan Waktu Kerja Wanita Tani dalam Kegiatan Ekonomi

\begin{tabular}{|c|c|c|c|}
\hline Kategori & $\begin{array}{l}\text { Kegiatan } \\
\text { Ekonomi }\end{array}$ & $\begin{array}{c}\text { Curahan } \\
\text { Waktu Kerja } \\
\text { (jam/minggu) }\end{array}$ & $\begin{array}{c}\text { Persentase } \\
(\%)\end{array}$ \\
\hline \multirow{3}{*}{$\begin{array}{l}\text { On } \\
\text { Farm }\end{array}$} & Jambu & 1,07 & 48,42 \\
\hline & Jeruk & 1,14 & 51,58 \\
\hline & Jumlah & 2,21 & 100,00 \\
\hline \multirow{5}{*}{$\begin{array}{l}\text { Off } \\
\text { Farm }\end{array}$} & Buruh & & \\
\hline & Petik & 37 & 89,56 \\
\hline & $\begin{array}{l}\text { Melati } \\
\text { Gambir }\end{array}$ & 31 & 89,56 \\
\hline & Buruh Tani & 4,31 & 10,43 \\
\hline & Jumlah & 41,31 & 100,00 \\
\hline \multirow{3}{*}{$\begin{array}{l}\text { Non } \\
\text { Farm }\end{array}$} & $\begin{array}{l}\text { Pengrajin } \\
\text { Wig }\end{array}$ & 6,10 & 51,39 \\
\hline & Pedagang & 5,77 & 48,60 \\
\hline & Jumlah & 11,87 & 100,00 \\
\hline Total & & 55,39 & \\
\hline
\end{tabular}


Hasil penelitian menunjukkan bahwa rata-rata curahan waktu kerja wanita tani dalam berbagai kegiatan ekonomi mencapai 55,39 jam/minggu, sebagaimana ditunjukkan pada Tabel 1 . Menurut Scoones (1998), apabila curahan waktu kerja telah setara $1.600 \mathrm{jam} /$ tahun atau $133 \mathrm{jam}$ kerja/bulan atau 48 jam/minggu maka sudah mampu memberikan penghidupan kepada petani atau buruh tani. Secara umum, sumber penghidupan rumah tangga wanita tani berasal dari kegiatan on farm dengan menanam jambu dan jeruk di pekarangan rumah, kegiatan off farm dengan menjadi buruh petik melati gambir dan menjadi buruh tani, serta kegiatan non farm dengan menjadi pengrajin rambut palsu (wig) dan pedagang.

Pada kegiatan on farm sebagai petani jambu dan jeruk, wanita tani hanya menghabiskan waktu 2,21 jam/minggu. Kegiatan yang dilakukan berupa pengecekan apakah tanamannya tumbuh normal atau tidak. Wanita tani juga melihat apakah terdapat serangan hama dan penyakit tanaman atau tidak. Dua pekan sekali wanita tani membersihkan tanaman liar yang mengganggu tanaman jambu dan jeruk dengan sabit atau dicabut manual dengan tangan.
Kegiatan off farm sebagai buruh tani dilakukan oleh wanita tani apabila ada pemilik lahan yang membutuhkan jasa mereka untuk membersihkan lahan, melakukan pemupukan, penyemprotan pestisida, dan sebagainya. Kegiatan ini sifatnya tidak rutin dan umumnya dilakukan setelah kegiatan pemetikan melati gambir. Wanita tani mendapatkan upah sebesar Rp 20.000 - Rp 25.000 untuk pekerjaannya selama 2,5 - 3 jam.

Pada kegiatan non farm sebagai pengrajin rambut palsu (wig), wanita tani menghabiskan waktu selama 6,10 jam/minggu. Pekerjaan ini dikerjakan pada siang dan sore hari sepulang dari kegiatan pemetikan melati gambir. Wanita tani rata-rata mampu menyelesaikan rambut palsu (wig) sebanyak 2-3 wig dalam satu hari. Jumlah ini terhitung sedikit karena jenis pekerjaan ini membutuhkan ketelitian dan kesabaran. Dalam pekerjaan ini belum ada sistem pembayaran upah yang standar sehingga ada wanita yang mendapatkan upahnya setiap hari, setiap dua hari, ataupun setiap tiga hari, tergantung situasi dan kondisi.

Kegiatan non farm lainnya sebagai pedagang, dijalani oleh wanita tani dengan membuka warung di rumah, terutama bagi mereka yang memiliki 


\section{CURAHAN WAKTU KERJA WANITA TANI SEBAGAI BURUH PETIK MELATI GAMBIR DAN \\ KONTRIBUSINYA TERHADAP PENDAPATAN RUMAH TANGGA \\ Muhammad Fauzan, Ulil Martinah, Lestari Rahayu}

ekonomi cukup baik sehingga memiliki modal untuk usahanya. Kegiatan membuka warung ini dilakukan pada siang hingga sore hari sepulang dari kegiatan pemetikan melati gambir. Warung tersebut rata-rata menjual kebutuhan dapur seperti sayuran, bumbu masak, cemilan, dan sebagainya. Jenis kegiatan ekonomi ini terbilang lebih santai karena saat membuka warung, wanita tani masih bisa mengerjakan pekerjaan lainnya seperti mencuci pakaian, menyapu rumah dan halaman, serta kegiatan rumah tangga lainnya.

\section{Pendapatan Rumah Tangga}

Pendapatan rumah tangga buruh petik melati gambir berasal dari tiga kategori kegiatan, yaitu on farm, off farm, dan non farm. Selain dari wanita tani, sumber pendapatan rumah tangga juga berasal dari suami dan anggota keluarga lainnya meliputi kegiatan off farm sebagai buruh ternak dan kegiatan non farm sebagai buruh bangunan, penambang pasir, buruh pabrik, karyawan toko, serta uang kiriman.

Dalam satu bulan, wanita tani mampu memetik 59,63 kg melati gambir dengan harga jual Rp 10.000,-/kg sehingga pendapatan yang didapatkan sebesar Rp 596.346,-. Walaupun hasil yang didapat terbilang kecil, namun profesi sebagai buruh petik melati gambir masih menjadi pilihan utama bagi para wanita tani yang ada di lokasi peneltian. Beberapa hal yang menjadi penyebabnya antara lain:

1) Pendidikan

Mayoritas wanita tani yang hanya berpendidikan Sekolah Dasar (SD) menjadikan mereka tidak memiliki banyak pilihan dalam pekerjaan. Untuk menjadi buruh pabrik misalnya, pendidikan yang dipersyaratkan adalah Tamat Sekolah Menengah Pertama (SMP). Profesi buruh petik melati gambir yang tidak memerlukan persyaratan pendidikan tentu menjadi pilihan yang logis bagi para wanita tani.

2) Tekanan Ekonomi

Naiknya harga-harga kebutuhan pokok serta kecilnya pendapatan kepala keluarga sebagai buruh pabrik, buruh ternak, dan buruh bangunan musiman membuat kaum wanita sebagai istri tidak punya pilihan lain selain ikut bekerja untuk membantu ekonomi rumah tangga. Karakteristik pekerjaan sebagai buruh petik yang tidak memerlukan modal menjadikannya sebagai pilihan utama bagi kaum wanita.

3) Tidak Ada Pekerjaan Lainnya 
Wanita tani yang bekerja sebagai buruh petik melatih gambir umumnya tidak memiliki lahan pertanian sendiri, selain pekarangan di sekitar rumah. Hal ini membuat mereka tidak punya banyak pilihan dalam berusahatani selain menjadi buruh petik.

4) Tidak Memerlukan Ketrampilan Khusus

Pekerjaan menjadi buruh petik melati gambir bisa dilakukan semua orang karena tidak memerlukan keterampilan khusus. Umumnya wanita tani yang pertama kali mencoba menjadi buruh petik dapat langsung belajar secara mandiri dengan mempraktikkannya dan bertanya kepada buruh petik lainnya.

Pendapatan wanita tani dari pekerjaan sebagai buruh petik melati gambir mampu memberikan kontribusi sebesar $25,58 \%$ terhadap pendapatan total rumah tangga, sebagaimana bisa dilihat pada Tabel 2. Angka ini termasuk besar jika melihat posisinya sebagai istri yang masih harus mengerjakan pekerjaan rumah sehari-hari. Sinadia et al (2017) menyatakan bahwa kaum perempuan yang bekerja sebagai buruh memiliki alasan yaitu ingin membantu suami meningkatkan ekonomi keluarga, ingin mengembangkan diri dan mengikuti lingkungan kehidupan sekitar (tetangga, teman, atau saudara). Pendapatan yang diperoleh sangat membantu suami dalam menstabilkan ekonomi keluarga. Tanpa kontribusi dari kaum perempuan, kebutuhan dalam keluarga belum dapat tercukupi.

Tabel 2. Sumber Pendapatan Rumah Tangga Buruh Petik Melati Gambir Per Bulan

\begin{tabular}{|c|c|c|c|}
\hline $\begin{array}{c}\text { Sumber } \\
\text { Pendapatan } \\
\end{array}$ & Kegiatan & $\begin{array}{c}\text { Pendapatan } \\
\text { (Rp) } \\
\end{array}$ & $\begin{array}{c}\text { Persentase } \\
(\%) \\
\end{array}$ \\
\hline \multirow{2}{*}{$\begin{array}{c}\text { On Farm } \\
\text { (Wanita } \\
\text { Tani) }\end{array}$} & Jambu & 22.157 & 0,95 \\
\hline & Jeruk & 340.028 & 14,59 \\
\hline \multicolumn{2}{|c|}{ Jumlah } & 362.185 & \\
\hline \multirow{2}{*}{$\begin{array}{c}\text { Off Farm } \\
\text { (Wanita } \\
\text { Tani) }\end{array}$} & $\begin{array}{l}\text { Buruh petik } \\
\text { melati } \\
\text { gambir }\end{array}$ & 596.346 & 25,58 \\
\hline & Buruh tani & 283.942 & 12,18 \\
\hline $\begin{array}{c}\text { Off Farm } \\
\text { (Suami) }\end{array}$ & $\begin{array}{l}\text { Buruh } \\
\text { Ternak }\end{array}$ & 201.923 & 8,66 \\
\hline \multicolumn{2}{|c|}{ Jumlah } & 1.082 .211 & \\
\hline \multirow{3}{*}{$\begin{array}{c}\text { Non Farm } \\
\text { (Wanita } \\
\text { Tani) }\end{array}$} & $\begin{array}{l}\text { Pengrajin } \\
\text { wig }\end{array}$ & 296.250 & 12,71 \\
\hline & $\begin{array}{l}\text { Pengrajın } \\
\text { kayu }\end{array}$ & 28.846 & 1,24 \\
\hline & Pedagang & 180.385 & 7,74 \\
\hline \multirow{5}{*}{$\begin{array}{c}\text { Non Farm } \\
\text { (Suami dan } \\
\text { Anak) }\end{array}$} & $\begin{array}{l}\text { Buruh } \\
\text { bangunan }\end{array}$ & 45.577 & 1,96 \\
\hline & $\begin{array}{l}\text { Penambang } \\
\text { pasir }\end{array}$ & 22.115 & 0,95 \\
\hline & $\begin{array}{l}\text { Buruh } \\
\text { pabrik }\end{array}$ & 211.538 & 9,07 \\
\hline & $\begin{array}{l}\text { Karyawan } \\
\text { toko }\end{array}$ & 27.885 & 1,20 \\
\hline & $\begin{array}{l}\text { Uang } \\
\text { kiriman }\end{array}$ & 74.038 & 3,18 \\
\hline \multicolumn{2}{|c|}{ Jumlah } & 886.634 & \\
\hline \multicolumn{2}{|c|}{$\begin{array}{c}\text { Total Pendapatan Rumah } \\
\text { Tangga } \\
\end{array}$} & 2.331.030 & 100,00 \\
\hline
\end{tabular}

Selain dari profesi sebagai buruh petik, wanita tani juga mendapatkan pendapatan dari kegiatan on farm berupa usahatani jambu dan jeruk sebesar $\mathrm{Rp}$ 362.185,-/bulan. Hasil tersebut mampu memberikan kontribusi sebesar 15,54\% 


\section{CURAHAN WAKTU KERJA WANITA TANI SEBAGAI BURUH PETIK MELATI GAMBIR DAN \\ KONTRIBUSINYA TERHADAP PENDAPATAN RUMAH TANGGA \\ Muhammad Fauzan, Ulil Martinah, Lestari Rahayu}

terhadap pendapatan total rumah tangga.

Dari kegiatan non farm, wanita tani bersama dengan anggota keluarga lainnya (suami dan anak) mendapatkan pendapatan sebesar Rp 886.634,-/bulan dan memberikan kontribusi sebesar $38,04 \%$ terhadap pendapatan total rumah tangga.

Hasil analisis menunjukkan bahwa total pendapatan rumah tangga buruh petik melati gambir adalah sebesar $\mathrm{Rp}$ 2.331.030,-/bulan. Sumber pendapatan rumah tangga terbesar berasal dari pekerjaan sebagai buruh petik melati gambir yang mampu memberikan kontribusi sebesar 25,58\%. Besar pendapatan ini sudah berada diatas Upah Minimum Kabupaten Purbalingga. Artinya rumah tangga buruh petik melati gambir sudah mampu memenuhi kebutuhan dasarnya sehari-hari.

\section{KESIMPULAN DAN SARAN}

Curahan waktu kerja wanita tani sebagai buruh petik melati gambir adalah sebesar 37 jam/minggu. Pendapatan buruh petik melati gambir sebesar $\mathrm{Rp}$ 596.346,-/bulan dan memberikan kontribusi sebesar $25,58 \%$ terhadap pendapatan total rumah tangga. Peningkatan pendapatan buruh petik dapat dilakukan dengan meningkatkan jumlah hasil petikannya.

\section{DAFTAR PUSTAKA}

Faqih, A. (2011). Kependudukan : Teori, fakta dan masalah. Yogyakarta : Dee Publish

Fauzan, M. (2016). Pendapatan, risiko, dan efisiensi ekonomi usahatani bawang merah di Kabupaten Bantul. AGRARIS: Journal of Agribusiness and Rural Development Research, 2(2), 107117.

Lailandra, A., Fauzan, M., \& Fivintari, F.R. (2019). Curahan Waktu Kerja Buruh Petik Bawang Merah di Kabupaten Brebes. Prosiding Seminar Nasional 2019 : Peran dan Strategi Sektor Pertanian Memasuki Era Industri 4.0., 456466

Mausyaroh, R., Mollo, M., \& Wibowo, A. (2010). Kontribusi Pendapatan Pemetik Daun Teh terhadap Pemenuhan Kebutuhan Hidup Rumah Tangga di Desa Kemuning Kecamatan Ngargoyoso Kabupaten Karanganyar. J. Pertanian, 36, 1-14. Purba, A.R.D., Sayekti, A.A.S., \& Juita, N.R. (2017). Tingkat Kesejahteraan Ekonomi Karyawan Pemetik Teh di PTPN IV Unit Bah Butong Provinsi Sumatera Utara. Jurnal Masepi, 2(1).

Risnawati, R., \& Tridakusumah, A.C. (2020). Kontribusi Remitansi Perempuan terhadap Rumah Tangga Petani di Kabupaten Indramayu. Mimbar Agribisnis: Jurnal Pemikiran Masyarakat Ilmiah Berwawasan Agribisnis, 6(1), 422-432.

Scoones, I. (1998). Sustainabel rural livelihoods :a framework for 
analysis, IDS Working Paper 72. Bringhton : University of Sussex

Sinadia, J. B., Wangke, W. M., \& Benu, N. M. (2017). Kontribusi Buruh Perempuan terhadap Pendapatan Keluarga (Studi Kasus Tempat Pelelangan Ikan di Tumumpa Kota Manado). Agri-Sosioekonomi, 13(1A), 253-260.

Suratiyah, K. (1994). Konsep-konsep kegiatan off-farm. Jurnal Populasi, $5(1)$
Wibawa, D.R. (2017). Kontribusi Pendapatan Buruh Wanita Pemetik Teh terhadap Total Pendapatan Rumah Tangga di Agrowisata Kebun Teh Semugih Desa Banyumudal Kecamatan Moga Kabupaten Pemalang. Geo Educasia-S1, 2(5), 657-671. 